\title{
The Joint Arabic Investments Role at Aqaba Special Economic Zone: Marsa Zayed as a Model
}

\author{
Hanem Rajab Ibrahem Al-Darwesh ${ }^{1}$ \\ ${ }^{1}$ Aqaba College, Al-Balqa' Applied University, Aqaba, Jordan \\ Correspondence: Hanem Rajab Ibrahem Al-Darwesh, Aqaba College, Al-Balqa' Applied University, Aqaba, \\ Jordan. E-mail: hanemaldarwesh@yahoo.com
}

Received: June 19, 2017

Accepted: July 6, 2017

Online Published: July 20, 2017

doi:10.5539/ijef.v9n9p22

URL: https://doi.org/10.5539/ijef.v9n9p22

\begin{abstract}
The study addressed the role of Arabic investments in Aqaba special economic zone (ASEZ), and tried to answer the following questions: are the necessary potentials and features available in (ASEZ) to provide an attractive investment climate for the Arabic investments, what is the level of policies effectiveness for improving the investment climate in (ASEZ) to attract the Arabic investments, what is the level of guarantees effectiveness provided by (ASEZ) to encourage Arabic investments, and what is the level of investment privileges and facilities, related to the investments provided by (ASEZ) to attract the Arab investment to it. Data were collected through one study tool that consisted of 30 paragraphs by using Likert fifth scale. Study importance comes from its benefit to decision makers at (ASEZ) to avoid some of the pitfalls and barriers that face the investment in it, where the descriptive analytical approach was used to calculate the arithmetic means, standard deviations, percentages, and T-test on paragraphs of the questionnaire that was distributed by the simple random survey method. Study results showed the existence of distinctive characteristics within the investment climate at (ASEZ), and also concluded that (ASEZA) plays a big role in attracting Arabic investments to Aqaba, the study in return arrived to the existence of some barriers that limit the Arabic investments attraction to Aqaba, the most important of those are: management problems, multiple decision making parties, bureaucratic, and routine. The study recommended to reformulate operation of the united investment window, in a way that makes it a role model, to repair the internal house of government institutions and agencies dealing with investment, entrepreneurship or projects, and train staffs to facilitate the procedures offers for foreign investors, which encourage them to establish their projects there and improve the image of Jordan as an attractive country for investment and investors.
\end{abstract}

Keywords: analytical descriptive methods, Aqaba Special Economic Zone (ASEZ), Marsa Zayed, fifth Likert scale

\section{Introduction}

The dream of the Arab economic integration and cooperation had for long haunted the entire Arabic people, and as time passes, the political situations buildup, the division and lack in the middle east, and the absence of willingness, the dream becomes far-off , but like they say what doesn't grasp at most, doesn't leave it all, where there are still common denominators (geographic location, religion, language, culture, wealth, etc.) imposes on the Arabic countries a coordinative collective stand, and various forms of cooperation to defend the remainder of their interests, where in the context of globalization and the major economic, industrial, and financial multinationals, the individual work became a reason for additional disunity and division, as wolf eats the one sheep away from the herd.

Although, as a similar Arab conglomerates to face those multinationals is hard to achieve, they at least must cope with them, especially in the common explicit economical aspect by increase the size of Arabic known investments, provide a favorable investment climate that ensures free movement of capitals between the Arabic countries, insure the Arab investors and secure their investments, and provide them with compensation for losses resulting from the various risks.

Jordan has realized the benefits of joint Arab investment in increasing growth rates, develop its economy and infrastructure, and provide employment opportunities, along with the transfer of new and innovative technology and techniques, advanced manufacturing and industrials, management skills and expertise, and organizational 
capabilities. In this context, the Arab investment became one of the economic policies main goals to the decision makers in Jordan, and therefore initiated an early extensive reforms with the beginning of King Abdul Allah II era, as Jordan in April, 2000, engaged in the global economic system by getting the world trade organization membership and a number of its organizations, which means opening the world markets for Jordanian goods and services, Jordan willingness towards privatization, the liberalization of telecommunications and financial services, secure the intellectual property rights by issuing a law that protects the copyrights, trademarks and industrial designs, and Jordan has signed free trade agreements with many of the Arabic countries (Agadir agreement 2006), Jordanian European partnership agreement that went into effect in 2007, and the Us-Jordan free trade agreement that went into effect in 2001, in addition to the many trade agreements that aims to attract the Arabic investments to Jordan (Aqaba Special economic zone authority website).

In this context, the Hashemite Kingdom of Jordan government gave Aqaba region a great importance to make it viable and secure atmosphere for Arabic and foreign investments, Aqaba became special economic zone since 2001 under a special law to form starting point towards the establishment of a develop regional center at strategic location from the middle east to be a part of the economic integration development and multiple activities cycles that include tourism, professional services, multimodal transport, and value- added industries, which will provide investment opportunities on the international level, at this competitive area that distinguish with an Advance standard level of living. The Jordanian Government moved quickly to implement an ambitious plan to put Jordan on the world economy map, and the (ASEZ) establishment are among the key initiatives of this strategy to make it an investment development zone with multiple economic activities, which are a zone free of custom fees and most of the taxes, design a simplified investment environment by applying highly effective management systems and through a single investment window in order to attract investments, and increase the private sector participation in all aspects related to the management and development of the region. (Previous reference).

\subsection{Research Problem}

Trade and investment agreements signed by Jordan with a number of Arabic countries to attract investments, which some of them entered into effect, and completed the initial stages, the legislative reforms that adopted in the investments field and the related laws and regulations, and the primary goal of establishing (ASEZ) was creating good and attractive investment environment, and attract investors and Arabic businessmen, which provided many advantages, facilities, and exemptions. In this context, the following questions come to mind:

1) Are the necessary potentials and features available in (ASEZ) to provide an attractive investment climate for the Arabic investments?

2) What is the level of policies effectiveness at improving the investment climate in (ASEZ) to attract the Arabic investments?

3) What is the level of effectiveness provided by (ASEZ) to encourage Arabic investments?

4) What is the level of privileges and facilities contribution, related to the investments provided by (ASEZ) to attract the Arab investment to it?

\subsection{Research Objectives}

The research aims for the following:

1) Identify the adequacy level of necessary potentials and features available in (ASEZ) to provide an attractive investment climate for the Arabic investments.

2) Identify the nature of investment climate in (ASEZ) to attract the Arabic investments.

3) Identify the guarantees effectiveness level provided by (ASEZ) to encourage Arabic investments.

4) Identify the privileges and facilities contribution level, related to the investments provided by (ASEZ) to attract the Arab investment to it?

\subsection{Research Importance}

The importance of the research stems from the significant role of investments in the development of Hashemite kingdom of Jordan economy, through increasing the economic growth rate, which will reflect on upgrading the standard of living, prosperity, and welfare of the society. Importance of the research comes also from the importance of creating an investment climate to attract money holders and investors, in order to activate the relationships with the Arabic countries, which reflect the economies openness between the Hashemite Kingdom of Jordan and the Arabic countries. 


\subsection{Research Hypotheses}

First hypothesis: Non-availability of the necessary potentials and features in (ASEZ) to provide an attractive investment climate for the Arabic investments.

Second hypothesis: Investment climate in (ASEZ) inappropriate to attract the Arabic investments.

Third hypothesis: insufficient guarantees provided by (ASEZ) to encourage Arabic investments.

Fourth hypothesis: privileges and facilities, related to the investments provided by (ASEZ) didn't contribute to attract the Arab investment to it.

\section{Previous Studies \& Literature Review}

Arabic foundation report for investment security and export recognition, investment climate report in the Arabic countries (2016) monitors the Arabic countries competitive position in attracting foreign direct investments, and includes a presentation and analysis for data and indicators related to performance of the Arabic countries groups, in terms of attracting external investment outflows by focusing on its appeal and attraction to those flows, according to a set of exponent variables for discrepancies and variances between the different world countries.

\subsection{Previous Studies}

Study of Loeil (2015) about the reality and development of foreign direct investment in the Arab world and its perspectives, examined the evolution of intraregional foreign Arabic direct investment, and the study reviewed forms of foreign direct investment, from the perspective of both, the exporting countries of foreign investments and the receiving ones, as well as the forms of foreign investments according to direction and goal. The study spoke about the reality of intraregional Arabic investments which reveals a clear decline of its role in the Arabic economies, and there were problems behind the achievement of their desired role.

In regard to the economical indicators of the Jordanian industrial sector, the economic indicators bulletin of Jordanian industrial sector issued by Amman chamber of commerce and industry (2014), mentioned that macro economical indicators point that gross domestic product (GDP) grew in the first quarter of (2014) at (3.2\%) against (VS.) a growth of (2.6\%) during the same quarter of (2013), it also mentioned that unemployment rate for the first half of (2014) amounted to (11.9\%), where the unemployment rate fell during the second quarter of (2014) to (12\%), (10.4\% for males and $20.1 \%$ for females) Vs. (12.0\%) unemployment rate (10.3\% for males and $22.4 \%$ for females) during the same quarter of (2013), while the unemployment rate among university graduates amounted to $(16.6 \%)$.

Study of Kavanagh (2013) about the expected impacts on Aqaba population as a result of converting Aqaba to Special economic zone, this was referred to in the research: "Image transformation, the social and economical development in Aqaba, Jordan". The study aimed to search and examine the economic, tourism, and development transformations that were seen in Aqaba, which suppose to provide the local community with opportunities for empowerment to raise their standard of livings.

But the study of Taqah and others (2008) targeted the impact of Arabic investment on the Jordanian economy, through the research: "The Arab investment and its impact on the Jordanian economy, an analytical study", by analyzing the reality of Arabic investments in Jordan's economy and distinguish the contribution level of those investments in achieving positive results on the Jordanian economy structure and avoid economic problems and bottlenecks. The study discussed the concept of investment and its economic significance, and also dealt with the analysis of the Jordanian economy reality development during the period (1991-2005).

Although the study of Erekat (2007) about the investment climate and its challenges, " the investment climate in the Arab world, reality, obstacles and prospects" aimed to recognize the investment climate reality in the Arab world and the most important obstacles that faces investment, in addition to identify the future prospects of the investment climate in light of the twenty-first century challenges. The study concluded that potential (resources) investment at the societies considers one of the most important pillars for building a strong healthy national economy, one able to face and cope with the various challenges and solve many problems that the developing countries and Arabic countries suffers, such as unemployment, poverty, foreign debt, inflation, and so on.

Finally, the study of Bjewya (2005): "The Arabic known investments and their contributions to achieve the economic integration", addressed general information about investment and investment climate, and then examine the investment requirements and investment climate, and finally the study made a connection between investment climate and globalization through the contributed factors similar to the world investment climates and the impact of euro on the investment climate. Study reviewed the most important developments of investment climate in the Arabic countries, by studying the investment flows and the legislative developments of Arab 
countries, in the area of investment, as well as the economic developments, and the study gives details about the investment promotional efforts in the Arabic countries, as also the national efforts, and finally the new promotional arrangements that were taken by the Arabic countries to attract investment.

\subsection{Literatures Review (Related Works)}

In order to attract the foreign investments, countries offers incentives, facilities, privileges, and concessions as an encouragement to attract foreign investors. But the addition and differentiation of incentives and facilities only, doesn't necessarily means that it will achieve the flows of foreign investment to the host country, or increase its attractiveness, where the investors regardless of their nationality, don't give the high priority to incentives or facilities or privileges, but gives it to the political stability and to the natural, social, economical, managerial, and legal conditions in the host countries of investment, and known as the investment climate (Bjewya, 2005).

\subsubsection{Investment Climate}

Investment climate means overall conditions and circumstances that impact capital flow trends and operating it, countries political situation and extent of their stabilities, their administrative regulations and their effectiveness and efficiency, their legal systems clarity, constancy, balance with rights and burdens, the countries economical

policies and procedures, the nature of the market and its mechanisms, potentials from infrastructure and production factors, and the countries geographical and demographic characteristics. This entire so-called climate Investment (Erekat, 2007). But (Bjewya, 2005) identifies it as a set of economical, social, and legal circumstances, policies, and institutions that affect investor's confidence and convince them to direct their investments to one country or another.

\subsubsection{Investment Climate Potentials}

The political, social, economical, managerial, and legal conditions and situations formulate the major foundations to attract and encourage investment.

\section{1) Political and social situations}

Political stability in any country is the most important factor in attracting and encouraging local and foreign investments, and the economic indicators of countries that experience turbulences, instabilities, and conflicts confirm this fact, the results of Arabic economical conferences indicates that Arabic known investments were the most influence by the political and security developments in the Arabic region, where these investments dropped dramatically in size, in addition the nutritional gap reached (\$34) billion last year, and it's expected to reach (\$70) billion by 2030 (Investment issues Forum in the Arab world that held during the period (16-17/12/2015) organized by the Union of Arab businessmen). The political stability includes internal and external stability, meaning that internal security has to be sTable without disturbances, riots, demonstrations and civil disobedience and the external security means the non-existence of border problems between countries (Erekat, 2007), which is a distinguish advantage of Jordan, where it blesses with security and safety, thanks to Allah in spite of the wars and disturbances that some neighboring countries suffer. But the important question here is it enough for the country to attract investment by enjoying the political stabilities? Are there any other synchronize compounding factors with the political stability?

\section{2) Economical situations}

Economic stability resides in the economical policy clarity, tax system rationality, banking system efficiency, the possibility to transfer profits and capital externally without restrictions, guarantees and concessions existence, custom reductions on production requirements, free exchangeable cash system without restrictions, financial stocks and free exchange market, banks offering low interest loans and facilities, broad domestic market, consumers with large purchasing power, financial incentives, guarantee investments of all commercial and non-commercial risks, the stability of currency, and others.

Usually foreign investors avoid the countries known for high inflation rates, as this will force them to take preventive action to limit or reduce it, based on the traditional fiscal and financial policies that influence the foreign trade structure and exchange rates (Bjewya, 2005).

The majority of Arabic countries are experiencing poor economic conditions, such as weak economical structures and their dependences on one or two sources of income, or lack of diversification in the productive structure, external debt increase, unemployment and poverty, technical gap, and economical dependency (Erekat, 2007).

Meanwhile, the business environment and investment climate in the Arabic countries needs more reforms through investment laws reviews and grants additional incentives for investors, along with the require funds for 
investment (previous reference).

Macroeconomic stability considers one of the important factors to attract investment, where this stability and its degree will be measured by seven basic variables: instability level of the real (GDP) growth rate, inflation rate, instability of real effective exchange price, number of exchange-rate crises during the last ten years, current account ratio to (GDP), Public budget ratio to (GDP), and total public debt ratio to (GDP). Arab oriental (eastern) countries (Egypt, Lebanon, and Jordan) ranked third with a value of 8.16 points and very weak performance level, and their performance level for the secondary variables were between weak and very weak (The Arabic foundation of investment guarantee and exports credential, 2016).

3) Managerial situations

Some Arabic countries still suffers from numerous managerial problems, which can be summarized as follows:

a. The bureaucracy and routine in procedures and transactions completion.

b. Lack of expertise and specialized technical staffs.

c. Lack of managerial leaderships with the entail skill in investment project management.

d. Non-existence of advance information systems.

e. Non-existence of information and data accuracy.

f. Non-replacement of the right man in the right place.

g. Non-focus on training to refine and increase the employee capacity at work.

h. Lack of development and upgrading of managerial devices.

i. Hiring isn't based on efficiency and capability, but on sectarianism, factionalism, ideological, and tribe.

j. Non-availability of existing investment opportunities and scientifically designed investment a maps.

k. Most projects have deficiency in the feasibility studies.

1. Multiple supervising devices on investment in most of the Arabic countries (Erekat, 2007).

4) Legal situations

The conditions and situations in most of Arabic countries can be represented in the following:

1) The instability of laws that encourage investment in general, which leads to damage the investor confidence.

2) Conflicts of some articles or items in the laws of some Arabic countries.

3) Some laws in some of the Arabic countries improper to the developments, situations, advancements, and changes in the world.

4) Laws ambiguity and the dependency on diligence explanation in some Arabic countries. (Previous reference).

The institutional, organizational and administrative conditions have clear impact on the investment climate, especially the laws and legislation, and the guarantee of their continuity, stability, implementation level, and their consistency with the international commercial laws and overall monetary and financial policies, and also the structural, legal, and institutional reform gives investor confidence in the assessment stage of the target geographic area selections of investment, where the risk and costs decrease as a result of rules, laws, and methods clarity of the target investment environment, besides reduce the uncertainty in the future, when investor face regular or legal constraints that affect the functioning and sustainability of the investment process. According to the institutional environment index, the Arabic countries performance were very modest, where the Arabic countries achieved an average index value of (36.7) points compares with (51.4) points at the international average. The Arab gulf countries ranked first on the Arab level with (52.9) points and medium performance, followed by the western Arab countries at second place with (36.4) points and poor performance, and eastern Arab countries ranked third with (34.1) points with also poor performance (Arabic institution for investment guarantee and exports credential, 2016).

\section{Investment Potentials in Jordan}

The investment in Jordan favored by several potentials that forms an important attraction factors, which makes from Jordan a unique investment destination that can be summarized as follows:

1) Unique strategic location in the heart of the Middle East and North Africa, that forms a strategic connection center between Europe, Asia, and Africa, and a focal point for access to more than one billion consumers. 
2) Strong relationships with the different world countries, particularly the Arabic countries which derives from the non-interfering declaration in others affairs.

3) Security and political stability in surroundings imbued with disturbances, political and security problems.

4) A group of trade agreements based on openness and integration policies, in addition to the (WTO) membership since 2000.

5) Macroeconomic stability and constancy, in spite of the difficult circumstances that facing it, and the sensationalism negative consequences and effects, due to the surrounding regional circumstances.

6) Efficient human resources qualified and trained workforce.

7) Exceptional infrastructure.

8) Advance and diverse economic sectors.

\subsection{Field One: Investment Potentials in Aqaba Special Economic Zone}

The historic city of Aqaba, as Jordan only seaport, locates on the Red Sea and it is the center for the special economic zone, which covers approximately an area of $\left(375 \mathrm{~km}^{2}\right)$ in the far south of the Hashemite kingdom of Jordan, and with $(27 \mathrm{~km})$ waterfront. Aqaba city population amount to approximately (80.000) and distinguish with the total integration infrastructure, social, and, logistic required to become a prosperous city, and developed and advanced regional center.

Investment fundamentals and potentials in the Aqaba region can be summarized as follows:

1) The (ASEZ) characterizes with strategic location that forms a connecting point of three continents and a crossroads for four countries, extends along the Jordanian coast on the Red Sea, and serves the area a modern seaport and an international airport.

2) Aqaba connects to the neighboring areas with ground road network that allows its users quick movement and its passengers and goods the security inside of Jordan dynamically and effectively.

3) It can be said that Aqaba natural advantages makes it an attractive tourist destination, and thus an ideal location for investment in the tourism sector.

4) Availability of high level infrastructure, international standards modern supported services, and electricity, water, and communication services.

5) Availability of Lands for real estate development, residential complexes and tourist projects establishment, logistics centers, warehouses, shopping centers, industrial cities, and technical production complexes (ASEZ) website.

\subsubsection{Investment Environment}

(ASEZ) made great efforts to create an appropriate investment climate for investors at all aspects and areas, including:

1) Simplifies registration and licensing procedures for the various economic activities, through unified investment window.

2) Remove restrictions on the percentage of foreign investment contribution in all areas of tourism, industrial, agricultural, commercial, and most services, except for certain professional services, there aren't any restrictions on profits and capitals transfer abroad, and also there aren't any restrictions on foreign currencies transactions .

3) Any project can hire foreign workers at (70\%), and in some cases can go over this percentage.

4) Lands can be leased for a period up to 50 years, and in special cases will be renewable for additional 50 years.

5) Investor can buy lands for the purpose of establishing hotels, and health, educational, residential, and commercial buildings, including multipurpose tourist complexes, warehouses, and public utilities, and in this case lands and properties sales tax will be paid.

6) Lands can be purchased at Aqaba international industrial zone to encourage investment in the industrial projects, for the purpose of establishing industrial projects (Alrai center for studies, 2015).

3.1.2 Expected Economical Activities Distribution, in Terms of Investment Size

Fig (1) clarifies the size or volume of investments in the anticipated various economic activities in (ASEZ), 
where the expected investments in the tourism sector formulates the higher percentage of investment at (50\%), followed by the service sector with $(30 \%)$, while the expected investments in the light industries sector formulated the least percentage (7\%), and amounted to (13\%) in the heavy industries sector.

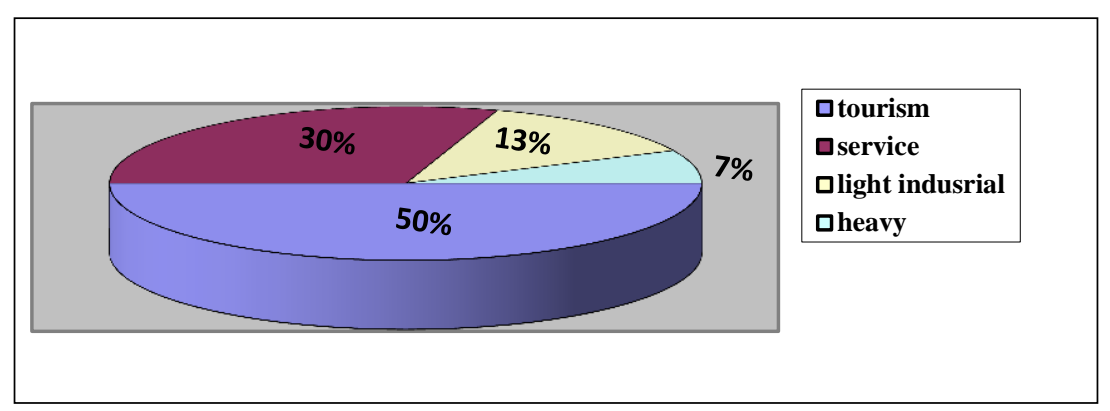

Figure 1. Expected economical activities distribution, in terms of investment size

Source: (ASEZA) technology website.

\subsubsection{Investment Opportunities}

Aqaba region provided investment opportunities in the various sectors, such as tourism, like resorts and spas, three, four, and five star hotels, apartments and residential buildings, amusement parks, sport fields, and sea cruises. As well as free markets and malls, tourist resorts and villages, convention centers, showrooms and fairs.

It also provided opportunities for investment in the industry sector, such as fertilizers and agricultural chemicals, cosmetics extracted from the dead sea, appliances and electronics, pharmaceutical, automotive and vehicle Assemblies, textiles and apparels, and food industries.

But with regard to the investment opportunities in services and development, Aqaba economic zone provided opportunities for investment in development and logistic services, such as cargo handling and clearance, aircraft maintenance, manufacturing and maintenance of small ships and boats, cargo storage and auctions, cargo freight and integrated logistic services, cold storage, and direct transport.

Aqaba economical zone also provided investment opportunities in the professional service level, such as engineering consultants, and information technology, including programming services, software development, and digital information programming and conversion, CAD/GIS, phone and digital communications centers, claims services achievement, medical and therapeutic centers and rehabilitation, printing, publishing, and Arabic and English translation, and internet services accommodation.

\subsection{Field Two: The Investment Climate Improvement Policies Effectiveness at (ASEZ) to Attract the Arabic Investments}

Jordan through the investment promotion institution plan deducts and identifies the investment opportunities and promote for it, provides full information and studies and clear picture of them, inform them of the most important sectors that they can invest in, where Jordan owns competitive advantages of it, provide and update information about the investment environment as a whole, and each sector separately. In addition, provide legislative and administrative information about the investment environment, such as visits programs preparation, schedule appointments with the competent authorities, provides information and data, and perform the registration and licensing procedures, on behalf of the investor for the investment projects with the official authorities. Jordan relies mostly in the promotion for its investment opportunities on audio, visual, and readable means, such as radio, newspapers, television, and the Internet.

Jordan also trains and rehabilitates the Jordanian diplomatic groups to strengthen their contribution to attract the high and added- value foreign investments to the Kingdom, provide them with the knowledge and scientific capability to do the task. And Jordan is heading today to promote the important role of embassies to strengthen the relationship with the private sector abroad, in order to attract the investments to the Kingdom and develop the economic relations with the world countries, as well as the coordination between the Jordanian economic departments and the Jordanian embassies abroad, which full under its efforts to make big shift in the social and economic situation in the Kingdom. The institution also depends on the representative offices abroad to promote for its investment opportunities, prepare the investment map, study the market, and gather the investment 
information which implemented by the institution.

As a result of the investment climate improvement policies at (ASEZ) to attract the Arabic investment, Aqaba economic region attracted many of the Arabic investments, and Marsa Zayed project was a model of these investments.

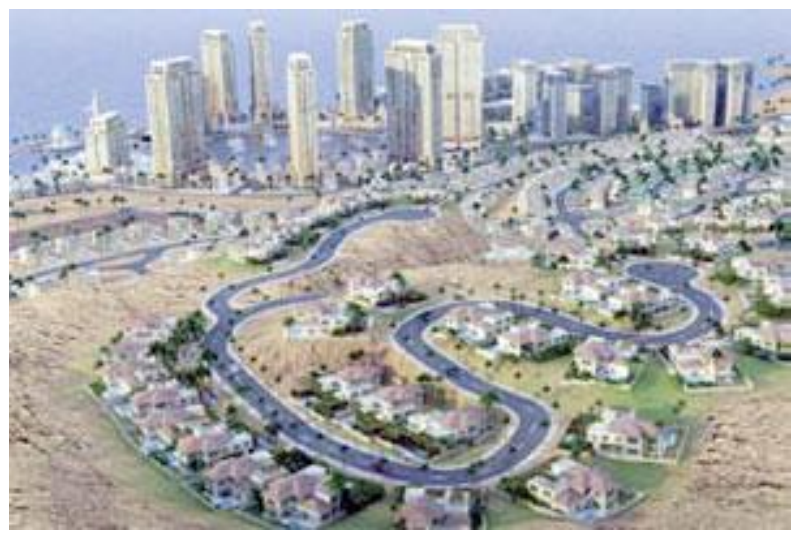

Figure 2. Marsa Zayed project

The economical, commercial, and social parties in (ASEZ) welcomed the launch of Marsa Zayed project

Infrastructure and engineering works in Aqaba, which leads to first phase completion of the largest investment project in the region.

It anticipated that Marsa Zayed project -as an investment of Emirate company (Al-Maber international company) - represents the capability of Aqaba economic zone to embrace huge projects that makes this economic area an attractive spot to serve all sectors of the neighboring and surroundings countries, particularly the gulf Arab states.

(ASEZ) intended from the opening of Marsa Zayed project and the beginning of its first phase to achieve several investment advantages, includes:

1) Investment environment in Aqaba zone is attractive and promising for the benefit of citizens and investors.

2) This project will contribute to serve the economic and commercial sectors and will provide several job opportunities for Jordanians (provide more than (15) thousand jobs, when completed), which its effects will reflect positively on the citizens welfare and life generally in Aqaba.

3) All sectors will experience rapid development and tourist mobility with the increasing pace of works at Marsa Zayed, will participate in moving the housing and real estate sector in unprecedented way, due to the employment volume in this project, and in all functional segments.

4) The project will push the real estate sector in Aqaba newly to the investment forefront, particularly in the areas that shows growing demand on construction and reconstruction, where it's expected that mortgages, real estate, lands prices will show increase with the launch of the project first phase.

5) Expectations to achieve a comprehensive development in the local community daily life aspects, provide job opportunities, and update and develop schools, health centers, roads, and the entire infrastructure by the project developers and owners (ASEZ).

It's worth mentioning that the United Arab Emirates (UAE) investments in Jordan, amounted to more than (\$15) billion. The most prominent Emirate investment projects and companies in Jordan are:

1) Marsa Zayed project in Aqaba city, under supervision of Al-Maber international company.

2) Dubai Capital Company has investments in energy, tourism, real estate, and finance sectors.

3) Jordan and Emirates Abaad company for commercial investments, UAE contribution in the company accounts to $50 \%$ from the capital of (10JDs) millions.

4) National bank of Abu Dhabi and Dubai Islamic bank, where it opens branches of it in Jordan, at the beginning of (2010) to provide banking and financial services. The volume of commercial exchange between the two countries amounted to (\$665) millions for the year (2010), according to the Jordanian indicators (embassy of UAE website, Amman). 
His Majesty King Abdullah II sponsored the celebration for launching the first phase of Marsa Zayed project in Aqaba city, which has been develop and implement by Al-Maber international company for investment, Jordan at investment cost that may reaches (10) billion dollars. The project aims to develop more than three million square meters of lands to build an integrated neighborhoods housing complexes, apartments, and towers, and the project that will provide more than (15) thousands jobs when completed, includes commercial markets, recreational facilities, hotels and resorts, and waterfront business parks and complexes that reach two kilometers long, in the marina district circuit which surrounded by the residential towers and tourist facilities that contains port and anchors for tourist boats and yachts (Addustour newspaper, 2010).

\subsection{Field Three: How Effective Are the Guarantees That (ASEZ) Provided to Encourage the Arabic Investments?}

\subsubsection{Investment Guarantees}

The Jordanian investment law or act for the year 2006, states the following:

Article 7, with taking into account the judgments of any other legislation:

a) Non-Jordanians are entitle to investment in the Kingdom by owning, participating, or contributing, in accordance with principles and conditions that will be define under a system issues for this purpose, determine according to it the investment sectors, their branches, the percentage limit that non-Jordanians investor entitles to participate or contribute in its, and the capital which investor must operate it for this purpose.

b) Non-Jordanian investor will be treated as the Jordanian investor, in the other cases that uncovered by the system referred to in paragraph (1) of this article.

Article $(8, \mathrm{~A})$ the phrase "invests foreign capital" for the purposes of this act means: any investments of non-Jordanian in the Kingdom, such as cash, or in-kind monies, or rights of financial value, including:

1) Money Transfers from the investor to the Kingdom.

2) Physical or in-kind assets imports by the investor.

3) Moral rights owned by the investor or any other person authorize to use it, which uses in the project, including concession rights, patents, trademark, and brand names.

4) Profits, dividends, and reserves resulting from foreign capital investment in the project, which uses to increase the project capital or invest in another project.

5) Project share results from capitalizing or exchanging investor debts on the project.

Article (8, B) Non-Jordanian investor has the right to the following:

1. Take out all or some of the foreign capital that investor brought to the Kingdom to invest in it, in accordance with the provisions of this law or the investment legislations that were in force, before this law went into effect.

2. Transfer or draft the dividends and profits that investor gains abroad.

3. Liquidates the investment or sells the project or shares of investor without delay.

Article $(8, \mathrm{C})$ Non-Jordanian investors take out the declared amounts in paragraph b of this article with convertible currency without any condition or restriction (The Jordanian investment act, 2006).

Despite all of these extensive guarantees, in reality the international economic indicators refers that Jordan fallback in the business practices rank, and according to the business practice report for the year 2016, issued by the international bank, Jordan ranked 113 on the general index from 189 countries participated in the report, falling back six degrees from its rank on 2015.

But in terms of guarantees related to the project initiation, article (12/c/1-2) of the Jordanian investment law requires the commissioner to issue permits required by the foreign investors, according to the conditions, requirements, and procedures no later than ten working days from the date of completion of the specified legal requirements in the document, otherwise the license consider issued by a verdict (The Jordanian investment act, 2006). The project initiation indicator particularly, illustrates a Jordanian decline in the number of licenses issues to investors, where Jordan rank dropped by 5 degrees down to 88 , as the project initiation requires 7 procedures and 12 days. The previous paragraph indicates that the problem is not in the legislation, but resides in the implementation of those legislations (The economical and industrial studies center, Amman chamber of industry, 2016).

In regard to the investor protection indicator, Jordan rank 163 within this indicator, and according to economists this rank consider disastrous, and this calls to stop at this number a lot, because it gives a negative impression about the investment environment in Jordan, its attractiveness for investment, and its protection for investors, 
and here we must be alert and work to improve the legislative environment and formulated it to ensure investors rights and justify them (The economic and industrial studies center, Amman chamber of industry, 2016).

The figures issued by the united nations conference for trade and development (UNCTAD) showed a drop in the size of foreign investment flows into Jordan during the year 2015, while these flows rose to some Arabic countries that faces several political or economical problems, and rationally Jordan must pass those countries to attract more of the foreign investment. Despite modification of the investment act to include numerous incentives for investors, but the indicator shows the main problem lies in the implementation of this law and in the government management of the investment process. Therefore, government must overcome the bureaucratic practices in all types of transactions and procedures needed by the investor, simplifies it and unites all sides that issues it, as well as being flexible when dealing with investors according to their projects, do whatever needed to keep them, and gives them comfort and stability (previous reference).

3.4 Field Four: What Is the Level o Facilities and Privileges Contribution Related to the Investment Provided by (ASEZ) Side to Attract Arab Investment to It?

To improve the investment climate in (ASEZ), the authorities in it adopted policies to provide the privileges and facilities for investors, in order to attract the Arabic investments to the region, for example:

Taxes and duties free imports:

1) Exempt all imports to the region from duties (except vehicles which can be exempt from charges by a special law).

2) Social services tax exemption.

3) Land and building tax exemption on exploited real estate.

4) Exemption of dividend and quotas distribution tax.

5) (5\%) tax on net income of any project, except banks, insurances, and road transport services which are subject to the applicable income tax in the customs area.

Sales tax deduction on the region sales of goods and services, except:

1) $(7 \%)$ sales tax is only imposed on twelve products, catering and hotels services, and tourist vehicle services.

2) Special tax on alcohol, tobacco, and cigarettes.

3) Exports abroad are subject to zero sales tax.

4) Easy entry of Jordanian origin goods into the international markets.

5) Jordan membership in the world trade organization (WTO).

6) Free trade agreements and protocols with numerous Arabic countries.

7) No restrictions on selling services and goods at the customs area, except for payment of the require duties and taxes when it entered.

Despite the privileges and facilities offers to investors, $(51 \%)$ of the participants in the questionnaire at the certified financial analyst institute of the international association for investment professionals expected Jordan investment opportunities to be medium in the next three years, while (35\%) except it to be good or excellent in the Kingdom, but half of the respondents in the survey believed that the best investment opportunities are available in Kingdom of Saudi Arabia (85\% of them excepted it as good or excellent opportunities).

\section{Research Methodology}

Research methodology depends on the descriptive method to describe the phenomenon by highlighting the investment climate in Aqaba economic zone, and also depends on the analytical method to analyze the level of Arabic investment success, as well as the guarantees, privileges, and facilities provided by (ASEZ) to encourage the Arabic investments.

\subsection{Research Society \& Sample}

The study society determine by the overall Arabic investments in (ASEZ), while the study sample represented by Marsa Zayed company, as a model for the Arabic investments in (ASEZ).

\subsection{Research Constraints and Limitations}

The research was limited to study the Arabic investments in (ASEZ), the available level of appropriate climate to attract the Arabic investments, and the guarantees and facilities that (ASEZ) provided for the protection of 
investors, in order to attract more of them.

Spatial boundaries: the study was limited to Aqaba city and the investment projects operating in (ASEZ).

Temporal boundaries: the study identified by the period of its tool distribution, which is in the month of June 2017.

Human boundaries: the study identified by the general and executives managers, and department heads in the investment companies operating in the various investment sectors in Aqaba, their number amount to 100 employees, and took 31 of them randomly for the study sample.

Subjective boundaries: subject of the study specified by the economic impact, and didn't overstep to the other effects that may result from the investments, such as social or political impact or any other impacts that may result from it.

\subsection{Research Methods and Tools}

The researcher unloaded and analyzed the questionnaire through the statistical package for social sciences (SPSS) software, and also depended on several statistical methods to analyze data, such as percentages and frequencies, Pearson correlation coefficient to measure the sincerity of paragraphs, Cronbach alpha test to identify the stability of paragraphs on the questionnaire, Spearman Brown formula for consistency, and the one sample T-test.

\section{Research Findings \& Results}

In this part of the research, the researcher will display the results of the study as follows:

First: the internal consistency of study fields:

Table 1. Reliability statistics

\begin{tabular}{cc}
\hline Number of items & Cronbach alpha \\
\hline 31 & 0.786 \\
\hline
\end{tabular}

It notes from Table (1) that alpha Cronbach coefficient amounted to (79\%), which is an accepTable value for this type of studies, the researcher calculated the arithmetic means, standard deviations, $\mathrm{T}$-value, and the statistical significance levels for all paragraphs in the study, and the results in Table (2) were as follows:

Table 2. Arithmetic averages, standard deviations, T-value, and statistical significance level for all study paragraphs

\begin{tabular}{|c|c|c|c|c|c|}
\hline Number & Paragraph & Arithmetic mean & STDEV & T-value & Siq \\
\hline 1 & $\begin{array}{l}\text { Aqaba owns a distinctive strategic location that makes it an attractive area } \\
\text { for investment }\end{array}$ & 4.19 & 0.86 & 26.760 & 0.000 \\
\hline 2 & Aqaba owns qualified, efficient, and trained human resources & 2.68 & 0.96 & 15.221 & 0.000 \\
\hline 3 & $\begin{array}{l}\text { Aqaba offers investors high level infrastructure, modern support services } \\
\text { within international standards, water, electricity, and communication } \\
\text { services. }\end{array}$ & 3.03 & 0.90 & 18.506 & 0.000 \\
\hline 4 & $\begin{array}{l}\text { Aqaba owns roads network that allows investors a quick and secure } \\
\text { movement of passengers and goods within Jordan dynamically and } \\
\text { effectively. }\end{array}$ & 3.81 & 0.59 & 35.259 & 0.000 \\
\hline 5 & $\begin{array}{l}\text { Aqaba natural advantages make it an attractive tourist destination and thus } \\
\text { an ideal location for investment in the tourism sector. }\end{array}$ & 3.97 & 0.82 & 26.425 & 0.000 \\
\hline 6 & $\begin{array}{l}\text { Aqaba works on streamlining registration and licensing procedures for the } \\
\text { various economic activities through a united investment window. }\end{array}$ & 2.28 & 0.63 & 31.371 & 0.000 \\
\hline 7 & Aqaba region provides investment opportunities in the various sectors. & 2.68 & 0.47 & 15.668 & 0.000 \\
\hline 8 & $\begin{array}{l}\text { Eliminate restrictions on the contribution percentage of foreign investment } \\
\text { in all fields helps attract investors. }\end{array}$ & 3.23 & 1.13 & 21.454 & 0.000 \\
\hline 9 & $\begin{array}{l}\text { Allow any foreign project to hire foreign workers within } 70 \% \text {, contributes } \\
\text { to attraction of investors. }\end{array}$ & 3.16 & 0.81 & 11.879 & 0.000 \\
\hline
\end{tabular}


10 Marsa Zayed project in Aqaba contribute to provide job opportunities for the local community, due to the volume of employment in all occupational segments.

11 Marsa Zayed project in Aqaba contributes to move tourism in it forward.

12 Marsa Zayed project in Aqaba contribute to move the housing sector, due to the volume of employment in the project.

13 Lands and real estate sector in Aqaba witnessed a real progress by launching Marsa Zayed project in it.

14 Aqaba saw development of infrastructure as a result of launching Marsa Zayed project in Aqaba.

15 Marsa Zayed project in Aqaba contributed to make the investment environment in it an attractive and promising one.

16 There are increase in the number of schools and health centers in Aqaba as a result of launching the project.

17 (ASEZ) provides sufficient guarantees for investors to encourage the Arabic investments to come to it.

18 Arab investors are relaxed about the provided guarantees effectiveness to protect their investments in Aqaba.

19 Security and political stability are the most important guarantee for investor's funds.

20 (ASEZ) perform researches and studies for the investors' expectations.

21 Jordan ranks as one of developed nations on the investor protection indicator.

22 (ASEZ) work to reduce the bureaucracy and routine in investment license issuing procedures.

23 ((ASEZ) work to support the processes of material costs reduction for investors and help them to invest in the business.

24 (ASEZ) devoted to provide investors special offices to offer them facilities. .

25 (ASEZ) perform permanent updates to simplify the registration and licensing procedures of economical activities.

26 Social services tax exemptions effectiveness is satisfactory for investors.

27 Land and buildings tax exemptions effectiveness use is satisfactory for investors.

28 Exclude personal relationships from the Arabic investments in (ASEZ).

29 Dividends distribution exemptions benefits are satisfactory for investors.

30 Lands renting benefit for 50 years, encourages investment in Aqaba.

\begin{tabular}{|c|c|c|c|}
\hline 2.71 & 1.25 & 30.803 & 0.000 \\
\hline 3.45 & 0.61 & 24.036 & 0.000 \\
\hline 2.94 & 0.67 & 16.524 & 0.000 \\
\hline 2.90 & 0.96 & 25.093 & 0.000 \\
\hline 3.06 & 0.67 & 19.505 & 0.000 \\
\hline 3.00 & 0.84 & 13.393 & 0.000 \\
\hline 2.81 & 1.15 & 14.772 & 0.000 \\
\hline 2.55 & 0.94 & 13.210 & 0.000 \\
\hline 2.52 & 1.04 & 18.626 & 0.000 \\
\hline 3.81 & 1.12 & 18.798 & 0.000 \\
\hline 3.26 & 0.95 & 14.544 & 0.000 \\
\hline 3.19 & 1.20 & 9.975 & 0.000 \\
\hline 1.77 & 0.97 & 10.811 & 0.000 \\
\hline 2.55 & 1.29 & 12.330 & 0.000 \\
\hline 2.48 & 1.10 & 11.499 & 0.000 \\
\hline 2.55 & 1.21 & 12.180 & 0.000 \\
\hline 2.45 & 1.10 & 24.623 & 0.000 \\
\hline 3.10 & 0.69 & 13.573 & 0.000 \\
\hline 2.42 & 0.98 & 22.399 & 0.000 \\
\hline 2.74 & 0.67 & 14.354 & 0.000 \\
\hline 2.74 & 1.05 & 19.745 & 0.000 \\
\hline
\end{tabular}

Table (2) indicates that the paragraph (22): "(ASEZ) work to reduce the bureaucracy and routine in investment license issuing procedures", has got the lowest arithmetic mean of (1.77) and a standard deviation of $(0,97)$, and the researcher believes the reason for that goes back to the problem of bureaucracy and routine in investment license issuing procedures, which represent one of the barriers for investment attraction in (ASEZ). This result agreed with (Erekat, 2007) study, which stated that some Arabic countries are experiencing several administrative problems, such as bureaucracy and routine in the procedures, completion of transactions, and the lack of expertise and specialized technical staffs.

While paragraph (1): "Aqaba owns a distinctive strategic location that makes it an attractive area for investment", got the highest arithmetic mean of (4.19) with a standard deviation of (0.86), and the researcher believes this result due to the unique strategic location that Aqaba owns, which makes it an attractive investment climate. This result agreed with (Alrai center for studies, 2015), which indicated that (ASEZ) made a big effort to create an appropriate investment climate for investors in all aspects, and fields.

Then the researcher examined the study fields, each area by itself, and Table (3) represents the first field: "availability level of investment potentials in (ASEZ)": 
Table 3. Availability level of investment potentials in (ASEZ)

\begin{tabular}{|c|c|c|c|}
\hline Number & Paragraph & Arithmetic mean & STDEV \\
\hline 1 & Aqaba owns a distinctive strategic location that makes it an attractive area for investment. & 4.19 & 0.86 \\
\hline 2 & Aqaba owns qualified, efficient, and trained human resources. & 2.68 & 0.96 \\
\hline 3 & $\begin{array}{l}\text { Aqaba offers investors high level infrastructure, modern support services within international } \\
\text { standards, water, electricity, and communication services. }\end{array}$ & 3.03 & 0.90 \\
\hline 4 & $\begin{array}{l}\text { Aqaba owns roads network that allows investors a quick and secure movement of passengers } \\
\text { and goods within Jordan dynamically and effectively. }\end{array}$ & 3.81 & 0.59 \\
\hline 5 & $\begin{array}{l}\text { Aqaba natural advantages make it an attractive tourist destination and thus an ideal location } \\
\text { for investment in the tourism sector. }\end{array}$ & 3.97 & 0.82 \\
\hline 6 & $\begin{array}{l}\text { Aqaba works on streamlining registration and licensing procedures for the various economic } \\
\text { activities through a united investment window. }\end{array}$ & 2.28 & 0.63 \\
\hline 7 & Aqaba region provides investment opportunities in the various sectors. & 2.68 & 0.47 \\
\hline 8 & $\begin{array}{l}\text { Eliminate restrictions on the contribution percentage of foreign investment in all fields helps } \\
\text { attract investors. }\end{array}$ & 3.23 & 1.13 \\
\hline \multirow[t]{2}{*}{9} & $\begin{array}{l}\text { Allow any foreign project to hire foreign workers within } 70 \% \text {, contributes to attraction of } \\
\text { investors. }\end{array}$ & 3.16 & 0.81 \\
\hline & Overall field & 3.22 & 1.02 \\
\hline
\end{tabular}

Table(3) indicates that the overall for the first field got an arithmetic mean of (3.22) with standard deviation of (1.02), and notes that paragraph (1) in this field: "Aqaba owns a distinctive strategic location that makes it an attractive area for investment", got the highest arithmetic mean of (4.19) with a standard deviation of (0.86), while paragraph (6): "Aqaba works on streamlining registration and licensing procedures for the various economic activities through a united investment window" got the lowest arithmetic mean of (2.28) with standard deviation of (0.63). Researcher sees this results to declare that (ASEZ) provide investment climate potentials, but the problem resides in procedures complexities, which is an absolute managerial problem that requires the search for solutions to attract investment. This result agrees with (Erekat, 2007) study, where it mentioned that absence of development and advancement in the managerial devices and the various supervising devices on investment at most of the Arabic countries, considers one of the most important managerial problems that expel investment, despite the availability of attractive and unique strategic location for investment, which is not everything.

To study the impact of the second field: "The effectiveness level of investment climate improvement policy at (ASEZ) to attract the Arabic investments", the researcher calculated the arithmetic means, and the standard deviations for this fields, and the results according to Table (4) were as follow:

Table 4. The effectiveness level of investment climate improvement policy at (ASEZ) to attract the Arabic investments

\begin{tabular}{|c|c|c|c|}
\hline Number & Paragraph & $\begin{array}{l}\text { Arithmetic } \\
\text { mean }\end{array}$ & STDEV \\
\hline 10 & $\begin{array}{l}\text { Marsa Zayed project in Aqaba contribute to provide job opportunities for the local community, due to } \\
\text { the volume of employment in all occupational segments. }\end{array}$ & 2.71 & 1.25 \\
\hline 11 & Marsa Zayed project in Aqaba contributes to move tourism in it forward. & 3.45 & 0.61 \\
\hline 12 & $\begin{array}{l}\text { Marsa Zayed project in Aqaba contribute to move the housing sector, due to the volume of employment } \\
\text { in the project. }\end{array}$ & 2.94 & 0.67 \\
\hline 13 & Lands and real estate sector in Aqaba witnessed a real progress by launching Marsa Zayed project in it. & 2.90 & 0.96 \\
\hline 14 & Aqaba saw development of infrastructure as a result of launching Marsa Zayed project in Aqaba. & 3.06 & 0.67 \\
\hline 15 & $\begin{array}{l}\text { Marsa Zayed project in Aqaba contributed to make the investment environment in it an attractive and } \\
\text { promising one. }\end{array}$ & 3.00 & 0.84 \\
\hline \multirow[t]{2}{*}{16} & $\begin{array}{l}\text { There are increase in the number of schools and health centers in Aqaba as a result of launching the } \\
\text { project. }\end{array}$ & 2.81 & 1.15 \\
\hline & Overall field & 2.98 & 0.94 \\
\hline
\end{tabular}

Table (4) indicates that second field overall got an arithmetic mean of (2.98) with standard deviation of (0.94), and notes that paragraph (10) in this field: "Marsa Zayed project in Aqaba contribute to provide job opportunities for the local community, due to the volume of employment in all occupational segments", got the lowest arithmetic mean of (2.71) with a standard deviation of (1.25). Researcher sees the reason for that may returns to the use of Arabic and foreign employments didn't provide real opportunities for the local community, which returns to the presence of gaps in the investment law that allow foreign investor to recruit foreign employment at (70\%) from the project employment size. This result agrees with (Alrai center for studies, 2015) study, where it mentioned that investment encouragement law allows any project to hire foreign employments at (70\%), with the 
possibility of exceeding this percentage in some cases, but the result itself disagree with the formal data and statements of (ASEZ), which said this project will contribute to the economical and commercial sectors service and will provide numerous job opportunities for the entire country (It will provide more than (15.000) job opportunities when finish), which will reflect positively on the life and welfare of citizens generally in Aqaba, while paragraph (11): "Marsa Zayed project contributes to move tourism in Aqaba forward", got the highest arithmetic mean of (3.45) with standard deviation of (0.61). Researcher sees the reason for this result is the tourism sector as the biggest beneficiary through the promotional expedition and large publicity for the project from the Arabic and local media. The reason for the low reading of this field returns to not distribute investment returns on all sectors.

To study the impact of the third field: "The effectiveness level of guarantees provided by (ASEZ) to encourage the Arabic investments", the researcher calculated the arithmetic means, and the standard deviations for this fields, and the results according to Table (5) were as follow:

Table 5. The effectiveness level of guarantees provided by (ASEZ) to encourage the Arabic investments

\begin{tabular}{clcc}
\hline \multirow{2}{*}{ Number } & \multicolumn{1}{c}{ Paragraph } & $\begin{array}{c}\text { Arithmetic } \\
\text { mean }\end{array}$ & STDEV \\
\hline 17 & (ASEZ) provides sufficient guarantees for investors to encourage the Arabic investments to come to it. & 2.55 & 0.94 \\
18 & Arab investors are relaxed about the provided guarantees effectiveness to protect their investments & 2.52 & 1.04 \\
& in Aqaba. & 2.94 & 0.67 \\
19 & Security and political stability are the most important guarantee for investor's funds. & 2.90 & 0.96 \\
20 & (ASEZ) perform researches and studies for the investors' expectations. & 3.06 & 0.67 \\
21 & Jordan ranks as one of developed nations on the investor protection indicator. & 3.00 & 0.97 \\
22 & (ASEZ) work to reduce the bureaucracy and routine in investment license issuing procedures. & $\mathbf{2 . 8 5}$ & $\mathbf{1 . 2 3}$ \\
\hline
\end{tabular}

Table(5) indicates that third field overall got an arithmetic mean of (2.85) with standard deviation of (1.23), and notes that paragraph (22) in this field: "(ASEZ) work to reduce the bureaucracy and routine in investment license issuing procedures", got the lowest arithmetic mean of (1.77) with a standard deviation of (0.97), while paragraph (19): "Security and political stability are the most important guarantee for investors funds", got the highest arithmetic mean of (3.81) with standard deviation of (1.12). Researcher refers this result to the security and political stability that Jordan enjoys which provides a secure and attractive investment climate and forms a real guarantee for investor's funds at (ASEZ), especially with the inflamed political situation in the areas adjacent to Jordan.

This result agrees with (Forum for investment issues in the Arab world, 2015) study, which noted that political stability in any country is the most important factor in attracting and encouraging local and foreign investments, and agrees also with (Erekat, 2007) study, where it indicate that political stability includes internal and external stability, internal security has to be sTable and steady without disturbances, riots, demonstrations, and civil disobedience, and the external security means no borders problems between countries.

To study the impact of the forth field: "level of facilities and privileges contribution related to the investment provided by (ASEZ) to attract Arab investment to it", the researcher calculated the arithmetic means, and the standard deviations for this field, and the results according to Table (6) were as follow:

Table 6. Level of facilities and privileges contribution related to the investment provided by (ASEZ) to attract Arab investment to it

\begin{tabular}{|c|c|c|c|}
\hline Number & Paragraph & Arithmetic mean & STDEV \\
\hline 23 & $\begin{array}{l}\text { (ASEZ) work to support the processes of material costs reduction for investors and help them } \\
\text { to invest in the business. }\end{array}$ & 2.55 & 1.29 \\
\hline 24 & (ASEZ) devoted to provide investors special offices to offer them facilities. . & 2.48 & 1.10 \\
\hline 25 & $\begin{array}{l}\text { (ASEZ) perform permanent updates to simplify the registration and licensing procedures of } \\
\text { economical activities. }\end{array}$ & 2.55 & 1.21 \\
\hline 26 & Social services tax exemptions effectiveness is satisfactory for investors. & 2.45 & 1.10 \\
\hline 27 & Land and buildings tax exemptions effectiveness use is satisfactory for investors. & 3.10 & 0.69 \\
\hline 28 & Exclude personal relationships from the Arabic investments in (ASEZ). & 2.42 & 0.98 \\
\hline 29 & Dividends distribution exemptions benefits are satisfactory for investors. & 2.74 & 0.67 \\
\hline \multirow[t]{2}{*}{30} & Lands renting benefit for 50 years, encourages investment in Aqaba. & 2.74 & 1.05 \\
\hline & Overall field & 2.63 & 1.06 \\
\hline
\end{tabular}


Table 6 indicates that fourth field overall got an arithmetic mean of (2.63) with standard deviation of (1.06), and the results refers to the paragraph (27) in this field: "land and buildings tax exemptions effectiveness use is satisfactory for investors", got the highest arithmetic mean of (3.10) with a standard deviation of (0.69), and the researcher sees this result as an encouragement to attract investment by the public and private facilities and exemptions, which Aqaba region grants to investors, and leads to increase investment size in the Aqaba region, while paragraph (28): "Exclude personal relationships from the Arabic investments in (ASEZ)", got the lowest arithmetic mean of (2.42) with a standard deviation of (0.98), and the researcher gives investment attraction as the reason for that, which requires numerous importance requirements. This result agrees with the (Bjewya 2005) study that the incentives and facilities enhancement and variation, don't necessarily means that it will bring the foreign investments to the host country, or increase its attractiveness, and regardless of the nationality, investor doesn't give priority to incentives, facilities, or privileges, but instead gives it to political stability and the natural, social, economical, legal, and administrative conditions in the host countries of investment.

Researcher generated the arithmetic means of those fields to compare them with each other, and the results according to Table 7 were as follow:

Table 7. Arithmetic means and the standard deviations for the four fields (areas)

\begin{tabular}{ccc}
\hline Field & Arithmetic mean & STDEV \\
\hline 1 & 3.22 & 1.02 \\
2 & 2.98 & 0.94 \\
3 & 2.85 & 1.23 \\
4 & 2.63 & 1.06 \\
\hline
\end{tabular}

Table 7 indicates that field (1): "Availability level of investment potentials in (ASEZ)", obtained the highest arithmetic mean of (3.22) with a standard deviation of (1.02), while field (4): "Level of facilities and privileges contribution related to the investment provided by (ASEZ) to attract Arab investments to it", got the lowest arithmetic mean of (2.36) with a standard deviation of (1.06). The researcher believes that the reason for that goes to Aqaba possession of an attractive investment potentials and features, but the problem resides in the bureaucracy and routine.

\section{Conclusions and Recommendations}

1) Review the way government deals with the investment attraction process, not by focusing on exhibitions and promotion, but through the internal house reform of government institutions and agencies that concerns about investment, project establishments, and trains staffs to facilitate procedures for foreign investors, which encourages them to launch their projects and improves the image of Jordan as an attractive country for investment and investors.

2) Reformulate and rework the unified investment window in a way that makes it a role model, through keeping it away from any government bureaucracy and giving a full authorities and commands to the delegates of the various parties working within the window, such as taking the approvals and decisions about all kinds of transactions and applications, as well as rehabilitate and train them on both professional and personal level.

3) Supply foreign investors unit inside the investment board with staffs, at high level of proficiency and the capability who cares about following up on anything relates to these investments, such as governmental transactions and procedures, whether within the board or outside of it from the various government institutions and entities, to accelerate these procedures and provide facilities for investors.

4) Activate the e-government to get the transactions and the approvals requires on it electronically, which facilitates and simplifies the procedures workflow and improves a lot in the work environment as a whole.

5) The quickness in financial insolvency law approval and draft it to provide the necessary guarantee for the protection of creditors, shareholders, and employees, which leads to motivate investment and stabilize the economic and social environment.

6) Improves the judicial environment and courts and keep it away from the procrastination in resolving commercial disputes and settle it, through more organizing and keeping judges or authorities from carrying many cross-cutting issues.

\section{References}

Addustour newspaper, Friday edition, (2010, May 28). 
Alrai center for studies, Aqaba special economic zone seminar, Opportunities and future prospects, 2015.

Aqaba special economic zone website.

Arab businessmen association. (2015). Investment issues forum in the Arab world, held in Aqaba during the period (16-17/12/2015).

Arabic foundation for investment guarantee and exports credit, 2016.

Arabic foundation of investment guarantee and exports credit report, investment climate report in the Arabic countries, 2016.

Bjewya, S. (2005). Arabic interdisciplinary investments and their contribution to achieve the economic integration. Master thesis, faculty of economic and management sciences, management sciences department, university of Algeria.

Center of economic and industrial studies, Amman chamber of industry, 2016.

Embassy of the UAE website, Amman, Jordan.

Erekat, H. (2007). The investment climate in the Arab world, the reality, obstacles, and future prospects. The fifth scientific conference of the faculty of administrative and financial sciences, Philadelphia university, Amman, Jordan.

Jordanian Investment Act, 2006.

Kimberly, K. C. (2013). Image transformation: social and economic development in Aqaba, Jordan. University of South Carolina. Retrieved from http://scholarcommons.sc.edu/etd/1964

Loeil, B. (2015). Evolution of foreign direct Arabic interdisciplinary investments. Arabic Economical Researches, 69\&70(winter \& spring), 2001.

Taqah et al. (2008). The Arab investment and its impact on the Jordanian economy, analytical study. Baghdad College University for Economic Sciences, 17.

The economical indicators bulletin of Jordanian industrial sector issued by the Amman chamber of industry, 2014.

\section{Appendix}

\section{Questionnaire}

Good greetings,

The researcher is preparing a study entitled: "The joint Arabic investments role at Aqaba special economic zone, Marsa Zayed as a model", where the questionnaire represents one of the important aspect in the research, would you kindly answer all the questions mentioned in the questionnaire, and provide the researcher with your valuable opinions, through placing the $(\mathrm{X})$ sign next to the answer that you sees it appropriate. The researcher also hopes that your answers will contribute to and raise the scientific level of this research.

Please note that all the questions mentioned in this questionnaire will be used for research purposes only, and your answers will be totally secret and under superior scientific care.

Thank you for your cooperation and your good response.

\section{Researcher}

\section{Section one: General information}

Please answer the questions that include general information, by placing an $(x)$ sign:

1. Sex:

\begin{tabular}{|c|c|c|}
\hline \multirow{3}{*}{ 2. Age: } & $\square$ Male & $\square$ Female \\
\hline & & \\
\hline & $\begin{array}{l}\square \text { More than } 50 \text { years } \\
\square \text { Between } 39-30 \text { years }\end{array}$ & $\begin{array}{l}\square \text { Between } 40-50 \text { years } \\
\square \text { Less than } 30 \text { years }\end{array}$ \\
\hline
\end{tabular}

3. Qualification:

$\square$ Bachelor $\quad \square$ Master $\quad \square \mathrm{PhD} \quad \square$ Others, please specify


4. Job title:

5. Experience:
$\square$ Executive manager
$\square$ Department head
$\square$ Others, please specify

$\square$ Less than 5 years

$\square$ From 10 to less than 15

$\square$ from 5 to less than 10 years

$\square$ from 15 to less than $20 \quad \square 20$ years and greater

\section{Section two:}

Field one: from your point of view: What is the availability level of the following investment potentials at (ASEZ)?

\begin{tabular}{|c|c|c|c|c|c|c|}
\hline Number & Paragraph & $\begin{array}{c}\text { Strongly } \\
\text { agree }\end{array}$ & Agree & Neutral & Disagree & $\begin{array}{l}\text { Strongly } \\
\text { disagree }\end{array}$ \\
\hline 1 & $\begin{array}{l}\text { Aqaba owns a distinctive strategic location that makes it an attractive area } \\
\text { for investment. }\end{array}$ & & & & & \\
\hline 2 & Aqaba owns qualified, efficient, and trained human resources. & & & & & \\
\hline 3 & $\begin{array}{l}\text { Aqaba offers investors high level infrastructure, modern support services } \\
\text { within international standards, water, electricity, and communication } \\
\text { services. }\end{array}$ & & & & & \\
\hline 4 & $\begin{array}{l}\text { Aqaba owns roads network that allows investors a quick and secure } \\
\text { movement of passengers and goods within Jordan dynamically and } \\
\text { effectively. }\end{array}$ & & & & & \\
\hline 5 & $\begin{array}{l}\text { Aqaba natural advantages make it an attractive tourist destination and } \\
\text { thus an ideal location for investment in the tourism sector. }\end{array}$ & & & & & \\
\hline 6 & $\begin{array}{l}\text { Aqaba works on streamlining registration and licensing procedures for } \\
\text { the various economic activities through a united investment window. }\end{array}$ & & & & & \\
\hline 7 & Aqaba region provides investment opportunities in the various sectors. & & & & & \\
\hline 8 & $\begin{array}{l}\text { Eliminate restrictions on the contribution percentage of foreign } \\
\text { investment in all fields helps attract investors. }\end{array}$ & & & & & \\
\hline 9 & $\begin{array}{l}\text { Allow any foreign project to hire foreign workers within } 70 \% \text {, contributes } \\
\text { to attraction of investors. }\end{array}$ & & & & & \\
\hline
\end{tabular}

Field two: from your point of view: What is the effectiveness level of the following investment climate improvement policies at (ASEZ) to attract the Arabic investments?

\begin{tabular}{|c|c|c|c|c|c|c|}
\hline Number & Paragraph & $\begin{array}{c}\text { Strongly } \\
\text { agree }\end{array}$ & Agree & Neutral & Disagree & $\begin{array}{l}\text { Strongly } \\
\text { disagree }\end{array}$ \\
\hline 10 & $\begin{array}{l}\text { Marsa Zayed project in Aqaba contribute to provide job opportunities for } \\
\text { the local community, due to the volume of employment in all } \\
\text { occupational segments. }\end{array}$ & & & & & \\
\hline 11 & Marsa Zayed project in Aqaba contributes to move tourism in it forward. & & & & & \\
\hline 12 & $\begin{array}{l}\text { Marsa Zayed project in Aqaba contribute to move the housing sector, due } \\
\text { to the volume of employment in the project. }\end{array}$ & & & & & \\
\hline 13 & $\begin{array}{l}\text { Lands and real estate sector in Aqaba witnessed a real progress by } \\
\text { launching Marsa Zayed project in it. }\end{array}$ & & & & & \\
\hline 14 & $\begin{array}{l}\text { Aqaba saw development of infrastructure as a result of launching Marsa } \\
\text { Zayed project in Aqaba. }\end{array}$ & & & & & \\
\hline 15 & $\begin{array}{l}\text { Marsa Zayed project in Aqaba contributed to make the investment } \\
\text { environment in it an attractive and promising one. }\end{array}$ & & & & & \\
\hline 16 & $\begin{array}{l}\text { There are increase in the number of schools and health centers in Aqaba } \\
\text { as a result of launching the project. }\end{array}$ & & & & & \\
\hline
\end{tabular}


Field three: from your point of view: What is the effectiveness level of the following guarantees provided by (ASEZ) to attract the Arabic investments?

\begin{tabular}{|c|c|c|c|c|c|}
\hline Number & Paragraph & $\begin{array}{l}\text { Strongly } \\
\text { agree }\end{array}$ & Agree & Neutral Disagree & $\begin{array}{l}\text { Strongly } \\
\text { disagree }\end{array}$ \\
\hline 17 & $\begin{array}{l}\text { (ASEZ) provides sufficient guarantees for investors to encourage the Arabic } \\
\text { investments to come to it. }\end{array}$ & & & & \\
\hline 18 & $\begin{array}{l}\text { Arab investors are relaxed about the provided guarantees effectiveness to } \\
\text { protect their investments in Aqaba. }\end{array}$ & & & & \\
\hline 19 & $\begin{array}{l}\text { Security and political stability are the most important guarantees for investor's } \\
\text { funds. }\end{array}$ & & & & \\
\hline 20 & (ASEZ) perform researches and studies for the investors' expectations. & & & & \\
\hline 21 & Jordan ranks as one of developed nations on the investor protection indicator. & & & & \\
\hline 22 & $\begin{array}{l}\text { (ASEZ) work to reduce the bureaucracy and routine in investment license } \\
\text { issuing procedures. }\end{array}$ & & & & \\
\hline
\end{tabular}

Field four: from your point of view: What is the contribution level of the following facilities and privileges related to investment and provided by (ASEZ) to attract the Arabic investment to it?

\begin{tabular}{|c|c|c|c|c|c|c|}
\hline Number & Paragraph & $\begin{array}{c}\text { Strongly } \\
\text { agree }\end{array}$ & Agree & Neutral & Disagree & $\begin{array}{l}\text { Strongly } \\
\text { disagree }\end{array}$ \\
\hline 23 & $\begin{array}{l}\text { (ASEZ) work to support the processes of material costs reduction for } \\
\text { investors and help them to invest in the business. }\end{array}$ & & & & & \\
\hline 24 & (ASEZ) devoted to provide investors special offices to offer them facilities. & & & & & \\
\hline 25 & $\begin{array}{l}\text { (ASEZ) perform permanent updates to simplify the registration and } \\
\text { licensing procedures of economical activities. }\end{array}$ & & & & & \\
\hline 26 & Social services tax exemptions effectiveness is satisfactory for investors. & & & & & \\
\hline 27 & $\begin{array}{l}\text { Land and buildings tax exemptions effectiveness use is satisfactory for } \\
\text { investors. }\end{array}$ & & & & & \\
\hline 28 & Exclude personal relationships from the Arabic investments in (ASEZ). & & & & & \\
\hline 29 & Dividends distribution exemptions benefits are satisfactory for investors. & & & & & \\
\hline 30 & Lands renting benefit for 50 years, encourages investment in Aqaba. & & & & & \\
\hline
\end{tabular}

Thank you for your time

\section{Copyrights}

Copyright for this article is retained by the author(s), with first publication rights granted to the journal.

This is an open-access article distributed under the terms and conditions of the Creative Commons Attribution license (http://creativecommons.org/licenses/by/4.0/). 